\title{
Global university rankings uncovered: introduction
}

\author{
Konstantinos I. Stergiou ${ }^{1,2, *}$, Athanassios C. Tsikliras ${ }^{1}$ \\ ${ }^{1}$ Institute of Marine Biological Resources and Inland Waters, Hellenic Centre for Marine Research, \\ Aghios Kosmas, 16777 Athens, Greece \\ ${ }^{2}$ Laboratory of Ichthyology, Department of Zoology, School of Biology, Aristotle University of Thessaloniki, UP Box 134, \\ 54124 Thessaloniki, Greece
}

\begin{abstract}
University rankings have gained growing attention from university administrations and faculty members, markets, governments, mass media and the public at large, affecting nearly all aspects directly or indirectly related to academia. This Theme Section includes 12 essays from 16 authors, coming from 9 countries (i.e. Singapore, the USA, the UK, Ireland, Belgium, Germany, Spain, Cyprus and Greece). These essays cover different methodological, socio-political, economical and ethical 'hot issues' emerging from the dominance of rankings in the higher education sector through the views and thoughts of different stakeholders (i.e. university administrators, people involved in performing the rankings, and scientists). We hope that this Theme Section and the questions it raises will further contribute to the recent debate and future of university rankings, whether they be global or regional, as well as help find the nexus between numbers (i.e. rankings) and knowledge (i.e. higher education institutions); to paraphrase Plato's quote 'a good decision is based on knowledge and not on numbers'.
\end{abstract}

KEY WORDS: Global university rankings · Higher education · Marketization of higher education · Ethics

\section{INTRODUCTION}

Higher learning institutions are known to have existed for over $4000 \mathrm{yr}$, with the Shangyang Higher School (established around 2250-2200 BC) and the Imperial Central School (established around 1050 BC), both in China, and other institutions in Pakistan (7th c. BC) and India (5th c. BC) (www.cwrl. utexas.edu/ bump/OriginUniversities.html) among the world's oldest. The most time-honored ancient university ${ }^{1}$ was Plato's Academy ${ }^{2}$ (also known as the Platonic Academy or Academy of Plato), with a history extending from $387 \mathrm{BC}$ to $529 \mathrm{AD}$, which held classes, gave lectures and builtup a library (Forbes 1833).

\footnotetext{
1The word 'university' is derived from the Latin universitas, which comes from the words universitas magistrorum et scholarium $=$ a community of teachers and scholars .
}

The word 'university' was coined for the Italian University of Bologna, which was founded in 1088 and is considered to be the first university in the sense of a higher-learning, degree-awarding institute. Today, there are about 21000 universities/

\footnotetext{
${ }^{2}$ The use of the Google Ngram viewer, which shows time series of the relative frequency of a phrase when compared to the frequency of all other phrases composed of the same number of words in the corpus of digitized books, shows that the relative frequency of usage of 'Plato's Academy', in its various forms, increased by one order of magnitude between 1800 and 1940-1960, i.e. from about 0.0000010 to about 0.000011 . The latter is higher than, for example, those of the universities of Lancaster, Essex, Warwick and Southampton in the UK and University of Calgary in Canada during this same time period (see Figs. S2 and S3 in the Supplement to Stergiou \& Tsikliras 2013). A detailed explanation and usage of the Google Ngram viewer is provided in Michel et al. (2011) and Lin et al. (2012), and as applied in rankings in Stergiou \& Tsikliras (2013).
} 
colleges $^{\underline{3}}$ in the world (www.webometrics.info) employing several million people and hosting more than 120 million students (UNESCO 2000), with international students in 2010 numbering more than 4.2 million (Robinson 2013, this Theme Section). Public expenditure on education was over 1.3 trillion US\$ in 1997 (UNESCO 2000) and the total expenditure on education in 2012 was over 4 trillion US\$ (Education Sector Factbook 2012). Thus, the education sector is, globally, the second largest 'industry' after healthcare, with the higher education market being very profitable for those countries that have invested in it. For instance, forprofit universities are among the 10 fastest growing industries in the USA (Setar \& MacFarland 2012). In addition, in 2011-2012, the international students studying in UK universities and colleges spent a total of $£ 3.9$ billion in tuition fees (net of scholarships), £6.3 billion in living expenses and $£ 1.1$ billion in other activities related to higher education (e.g. research, academic and administration services) (Education Sector Factbook 2012).

Given the great importance of the education sector for the global economy and the sharply increasing number of internationally mobile students, especially those from China ${ }^{4}$ and India, who represent a huge pool of potential internationally mobile students ${ }^{\mathbf{5}}$ (Fischer 2013, Larson 2013), the development of a numerical tool for the assessment of higher education institutions (i.e. university rankings), which could be used by universities to attract students, was consequential.

\section{GLOBAL UNIVERSITY RANKINGS}

Although university rankings have a long history (e.g. classifications of US universities in the 1880s, Salmi \& Saroyan 2007; ranking of university graduate programs in 1925, Hughes 1925; rankings in 1958, Caplow \& McGee 1958; the 1973 Carnegie Commission's classification listings of colleges and

\footnotetext{
${ }^{3}$ The word 'college' is derived from the Latin collegium and refers to an educational institution or a constituent part of one (the usage varies among English-speaking countries). ${ }^{4}$ The number of Chinese students enrolled at US colleges increased from nearly 62000 students in 2003-2004 to 236000 students in 2012-2013 (Larson 2013).

${ }^{5}$ By 2024, the number of Chinese students pursuing university studies outside China is expected to reach 850 000. Chinese and Indian students studying outside their countries are expected to account for about $35 \%$ of international students (Fischer 2013).
}

universities, McCormick \& Zhao 2005), what are nowadays known as 'global ${ }^{\mathbf{6}}$ university ranking' systems first appeared in 2003 with the publication of the Shanghai ranking - now known as the Academic Ranking of World Universities (ARWU) (Liu \& Cheng 2005). Since then, more than 12 global ranking systems have been developed (e.g. the Times Higher Education, Webometrics, Quacquarelli Symonds, the U-multirank) together with several regional and national ones (for Europe, Asia, the Americas and Oceania) (Rauhvargers 2011, 2013, Jarocka 2012). Global university ranking systems use various criteria to produce their league tables (see Rauhvargers 2011, 2013 and Taylor et al. 2014 in this Theme Section for a detailed account of the different ranking systems as well as their indicators, methodology and limitations), including the scientific performance and scientific recognition of academic staff, employer and peer reputation, the number of international staff and students and admissions policies.

The large number of recent books and reports by international organizations (e.g. Hazelkorn 2011, Rauhvargers 2011, 2013, Shin et al. 2011, Lo 2012, Shin \& Kehm 2012, Wildavsky 2012, Climent et al. 2013, Erkkilä 2013, Marope et al. 2013) and scientific articles dedicated to university rankings certainly indicate that ranking is an important matter of debate and area of work within higher education. For instance, from 1978-2012, more than 200 articles were published on university rankings, with the number of articles increasing from $<3$ articles ${\mathrm{r}^{-1}}^{-1}$ during 1978-2004 to about 30 articles $\mathrm{yr}^{-1}$ in 2010-2012 (Stergiou \& Lessenich 2013, this Theme Section), with some of them being cited $>120$ times (e.g. Dill \& Soo 2005, Liu \& Cheng 2005, Lynch 2006, Marginson \& Van der Wende 2007, Hazelkorn 2008). At the same time, the frequency of usage of the phrase 'university rankings' in the corpus of digitized books was zero during 1950 to 1970 and started to slowly increase, probably because of the impact of the Carnegie Commission's classification listings of colleges and universities (McCormick \& Zhao 2005), although it continued to be low during the period from 1970 to 1983 (Fig. 1). From 1983 to 2008, however, the pattern in the frequency of usage changed (Fig. 1). Three main turning points are clearly observable, reflecting sharp increases in frequency (Fig. 1): (1) one in 1983, when the nowdefunct magazine U.S. News \& World Report compiled college rankings for the first time; $(2)$ a second

\footnotetext{
${ }^{6}$ but see note 1 in Stergiou \& Lessenich (2013).
} 


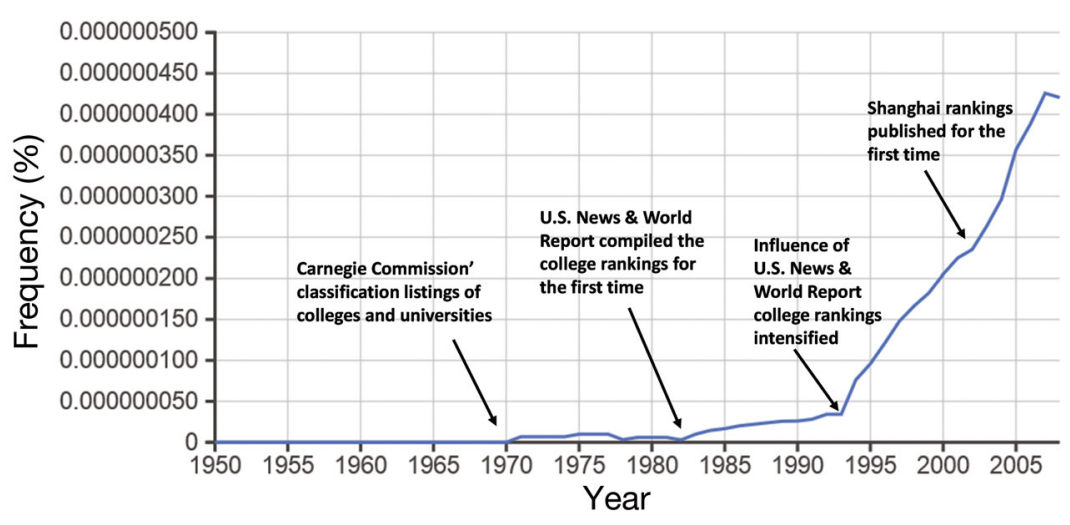

Fig. 1. Usage frequencies (relative) of the phrase (university rankings + University rankings) in the corpus of English books during 1950-2008

policy making, and the 'market' side of rankings; (3) whether or not rankings allow room for unethical behavior; (4) whether or not the pre-ranking reputation of universities is reflected in their meta-ranking status; and also (5) whether or not the social perception of university reputation is related to rankings.

We originally invited university administrators, post-graduate student societies, companies/institutions involved in performing the rankings and individual scientists to contribute their views on one or more of the above mentioned issues related to rankings. At the uni-

one in the early 1990s, when the influence of the U.S. News \& World Report college rankings intensified (Bowman \& Bastedo 2009); and (3) a third one in 2003, when the Shanghai rankings were published for the first time.

Nowadays, university rankings have gained growing attention from university administrations and faculty members, markets, governments, mass media and the public at large ${ }^{7}$. This is because university rankings affect all aspects directly or indirectly related to academia, such as university and departmental curricula, funding and reputation; student admissions, fees and job prospects; faculty member recruitment, promotion and wages; and publication records in terms of both quantity and quality (see Rauhvargers 2011, 2013, Stergiou \& Lessenich 2013).

\section{ISSUES UNCOVERED IN THIS THEME SECTION}

The present Theme Section aims to cast light on different 'hot issues' emerging from the dominance of rankings in the higher education sector through the views and thoughts of different stakeholders, i.e. scientists, university and business administrators, and people involved in performing the rankings. In particular, it aims to uncover (1) whether or not the methodologies used by ranking institutions ensure fair use of rankings in the comparison of disciplines, countries and continents; (2) whether or not the criteria used for rankings are based on academic performance or technicalities, the impact of rankings on

${ }^{7}$ For instance, university rankings were featured in the 2013 movie 'Admission', directed by Paul Weitz. versity administration level, our invitations were largely ignored with the exception of the Nanyang Technological University (which recently climbed up 83 positions in the global university rankings; www.straitstimes.com/breaking-news/singapore/story/ dramatic-leap-ntu-university-ranking-20121004) whose Deputy President and Provost (Prof. Boey) agreed to contribute (Lim \& Boey 2014, this Theme Section). Out of the 7 organizations/institutions performing rankings that we invited, only Times Higher Education chose to participate in such an exercise (Baty 2014, this Theme Section). With respect to individual scientists, the contributors are a mixture of academics who have previously worked on issues related to rankings (Amsler 2013, this Theme Section, Lynch 2013, this Theme Section, Robinson 2013, Turner 2013, this Theme Section Dearden et al. 2014, this Theme Section) as well as of others that have never before worked on such issues (Stergiou \& Tsikliras 2013, this Theme Section, Stratilatis 2014, this Theme Section, Taylor et al. 2014).

Overall, this Theme Section includes 12 essays from 16 authors, coming from 9 countries (i.e. Singapore, the USA, the UK, Ireland, Belgium, Germany, Spain, Cyprus and Greece) and from 3 continents. The background disciplines of the 16 authors are also very diverse (i.e. sociology, psychology, law, economics, business, marketing, education, environmental biology, biology and geography).

The contributions cover many different aspects of university rankings. Baty (2014) provides a brief history of the Times Higher Education world rankings powered by Thomson Reuters and describes the 'sample' characteristics of the Thomson Reuters' annual academic reputational surveys that support 2 key indicators for teaching and research. Baty also draws attention to various criticisms expressed $\underline{\underline{8}}$ in 
the literature. Lim \& Boey (2014) describe the institutional management structure, talent retention/ attraction, research competitiveness and international and industry collaborations of Nanyang Technological University that might have mediated its 83-position jump in rankings. Taylor et al. (2014) undertake a comparative analysis of 6 ranking systems and use the case of Greek universities to critically illustrate some of the various problems inherent in the ranking systems. They reveal that the rankings system serves as a commercial and stratifying tool that reproduces inequalities produced by global economics and production, and academic hierarchy. They also discuss what lies behind the 'madness' for rankings, and develop a protocol that can be used by potential users to assess the quality of higher education. Turner (2013) applies a new tool (Data Envelopment Analysis) to rankings and maintains that existing league tables do not take into account the cost of high-quality output, and are therefore not appropriate for the present period of adverse economic conditions where value-formoney rankings would certainly be more appropriate. Tsikliras et al. (2014, this Theme Section) examine the relationship of global university rankings with professorial salaries and university income, and extrapolate the findings to various European universities. They conclude that funding, autonomy and support by the parent state of a university is important for its position in rankings, and discuss the fate of European universities in several countries in relation to the recent economic crisis. Dearden et al. (2014) examine the US ranking system from the perspectives of 3 key factors (i.e. graduating high-school students, universities and ranking publications) and discuss potential inefficiencies in the system as well as possible unethical behavior by both universities and US companies producing the rankings. Stergiou \& Tsikliras (2013) show that the Google Ngram viewer (https://books.google. com/ngrams) is an easy-and-cheap-to-apply tool for approximating the reputation and 'intellectual' impact of universities over long time periods. They show that its reputation-generating capability, at least for top universities, is similar to that of commercial tools, a fact rendering the existence of commercial tools questionable.

\footnotetext{
${ }^{8}$ As Rauhvargers (2013) points out, Baty is one of the few persons involved in rankings who repeatedly draws attention to the various negative impacts, biases and flaws of the Times Higher Education rankings (e.g. Baty 2012a,b, 2013).
}

Lynch (2013) examines rankings within the neoliberal and new managerial contexts and shows that rankings are politically and commercially inspired, and that the institutionalization of new managerial norms is ensuring that universities are increasingly governed by market values that are reconstituting higher education. Moreover, she highlights the fact that rankings are nothing more than simple, easilyavailable numbers whose simplicity and accessibility masks their true political and moral purposes. Amsler (2013) draws attention to the ideological construction of rankings as a necessary and inevitable activity and to their symbolically violent character as a form of social categorization and hierarchization. Amsler makes a strong case for turning our back to rankings on scientific, ethical and political grounds. Stratilatis (2014) examines rankings across the natural versus social sciences divide and renders them as a knowledge/power instrument, potentially contributing to the process of the 'scientification' of social sciences and humanities. He concludes that, at least in regards to rankings and social sciences and humanities, no ranking system would be 'epistemically objective, value neutral and politically incontestable'. Robinson (2013) examines the limitations, biases and corrosive effects of rankings on higher education. He maintains that rankings encourage policy reforms and resource reallocation which, although they may improve the position of an institution in the rankings, do not necessarily improve research and teaching quality per se. Finally, Stergiou \& Lessenich (2013) explore the parallels in the birth, evolution and final boycotting of journal impact factors and university rankings, and conclude that the recent banning of impact factors (i.e. the San Francisco Declaration on Research Assessment, DORA, http://am.ascb.org/dora/) as well as of rankings (e.g. the recent boycott of German 'Centrum fuer Hochschulentwicklung' (CHE) rankings by German sociologists) are the first steps needed to be taken for academia to take control of its own metrics.

\section{EPILOGUE}

This Theme Section also raises new issues and questions to be tackled in future studies. Firstly, there is the question of whether or not rankings make unethical behavior easier, as has been shown to be the case with impact factors. Secondly, several articles in this Theme Section discuss the marketization of higher education. Is the decrease in tenured positions (e.g. USA, UK) and the appearance of strong voices in 
the news against tenure (e.g. Kaplan 2010) and in favor of cheaper, more flexible and insecure work contracts, in large part, a consequence of and a strategy to realize the marketization of higher education? Is there indeed a relationship between tenure, which is strongly impinging on academic freedom and the foundations of the modern university as we know it, and rankings and marketization? In addition, is there a danger of eliding the differences between the public interest values of universities and commercial values of businesses in the move towards marketization? Where will subjects that are not of market value and/or that may be critical of commercial values feature in future universities? And, finally, are we entering into a new era in which modern universities, an institutional form that is thousands of years old, are at risk of extinction by being transformed by a market practice (rankings) that is decades old?

Apart from the above-mentioned socio-political and ethical issues, there are also methodological issues raised from the present Theme Section. For instance, the efficiency and potential of the Google Ngram tool should be further tested using more universities from more countries in the context of both global rankings as well as of national rankings using the corpora of books in all 8 available languages (i.e. English, Spanish, German, French, Russian, Italian, Hebrew and Chinese). More importantly, however, given the positive relationship of several productivity-related indicators to an institute's wealth, the jury is still out on the question of whether or not the effective use of limited resources will substantially change the landscape of global university rankings.

We hope that this Theme Section and the questions it raises will further contribute to the recent debate and future of university rankings, whether they be global or regional, as well as help find the nexus between numbers (i.e. rankings) and knowledge (i.e. higher education institutions); to paraphrase Plato's quote 'a good decision is based on knowledge and not on numbers'.

Acknowledgements. We thank all the contributors participating in this Theme Section. We also thank S. Amsler, P. Baty, J. Dearden, S. Gialis, R. Grewal, S. Lessenich, G. Lilian, C. H. Lim, K. Lynch, A. Machias, D. Pauly, P. Perakakis, C. Stratilatis, M. Taylor and D. Turner and one anonymous reviewer for their useful comments and suggestions on this introduction.

\section{LITERATURE CITED}

Amsler (2013) University ranking: a dialogue on turning towards alternatives. Ethics Sci Environ Polit 13:155-166
Baty P (2012a) Rankings without reason. Inside High Educ, 31 May. www.insidehighered.com/views/2012/05/31/ essay-danger-countries-setting-policy-baseduniversityrankings (accessed 20 November 2013)

Baty P (2012b) Rankings don't tell the whole story - handle them with care. University World News Global Edition 227, 26 June 2012. www.universityworldnews.com/article. php? story $=20120626171938451$ (accessed 20 November 2013)

Baty P (2013) An evolving methodology: the Times Higher Education World University Rankings. In: Marope PTM, Wells PJ, Hazelkorn E (eds) Rankings and accountability in higher education - uses and misuses. UNESCO Publishing, Paris, p 41-54

Baty (2014) The Times Higher Education World University Rankings, 2004-2012. Ethics Sci Environ Polit 13: $125-130$

Bowman NA, Bastedo MN (2009) Getting on the front page: organizational reputation, status signals, and the impact of U.S. News and World Report on student decisions. Res High Educ 50:415-436

Caplow T, McGee RJ (1958) The academic marketplace. Basic Books, New York, NY

Climent V, Michavila F, Ripolles M (eds) (2013) Los rankings univeritarios: mitos y realidades, Ed Tecnos, Madrid

Dearden JA, Grewal R, Lilien GL (2014) Framing the university ranking game: actors, motivations, and actions. Ethics Sci Environ Polit 13:131-139

Dill DD, Soo M (2005) Academic quality, league tables, and public policy: a cross-national analysis of university ranking systems. High Educ 49:495-533

Education Sector Factbook (2012) GSV EDU. http://gsvadvisors.com/wordpress/wp-content/uploads/2012/04/GSVEDU-Factbook-Apr-13-2012.pdf (accessed 18 November 2013)

Erkkilä T (eds) (2013) Global university rankings: challenges for European higher education. Palgrave Macmillan, Basingstoke

Fischer K (2013) U.S. will be fastest-growing foreign-student destination, report predicts. Chron High Educ 8 October 2013. http://chronicle.com/article/US-Will-Be-FastestGrowing/142191/ (accessed 20 November 2013)

Forbes CA (1833) Ancient universities and student life. Class J 28:413-426

> Hazelkorn E (2008) Learning to live with league tables and ranking: the experience of institutional leaders. High Educ Policy 21:193-215

Hazelkorn E (2011) Rankings and the reshaping of higher education: the battle for world-class excellence. Palgrave Macmillan, Basingstoke

Hughes R (1925) A study of the graduate schools of America. Miami University Press, Miami, FL

Jarocka M (2012) University ranking systems - from league table to homogeneous groups of universities. World Acad Sci Engineer Technol 66:800-805

> Kaplan K (2010) The changing face of tenure. Nature 468: $123-125$

Larson C (2013) Students from China and Saudi Arabia flock to U.S. colleges. Global Economics. www.businessweek.com/articles/2013-11-12/students-from-china-andsaudi-arabia-increasingly-flock-to-u-dot-s-dot-colleges (accessed on 16 November 2013)

Lim CH, Boey F (2014) Strategies for academic and research excellence for a young university: perspectives from Singapore. Ethics Sci Environ Polit 13:113-123 
Lin Y, Michel J-B, Aiden EL, Orwant J, Brockman W, Petrov S (2012) Syntactic annotations for the Google Books Ngram corpus. Proc 50th Annu Meet Assoc Computational Linguistics Vol 2: Demo Papers, ACL, Jeju, 8-14 Jul, 2012

Liu NC, Cheng Y (2005) The academic ranking of world universities. High Educ Eur 30:127-136

Lo WYW (2012) Implications of university rankings for Taiwan's higher education. University of Bristol, Bristol

Lynch K (2006) Neo-liberalism and marketization: the implications for higher education. Eur Educ Res J 5: $1-17$

Lynch K (2013) New managerialism, neoliberalism and ranking. Ethics Sci Environ Polit 13:141-153

Marginson S, Van der Wende M (2007) To rank or to be ranked: the impact of global rankings in higher education. J Stud Int Educ 11:306-329

Marope PTM, Wells PJ, Hazelkorn E (eds) (2013) Rankings and accountability in higher education - uses and misuses. UNESCO Publishing, Paris

McCormick AC, Zhao C-M (2005) Rethinking and reframing the Carnegie classification. Change (September/October 2005):51-57

Michel JB, Shen YK, Aiden AP, Veres A, and others (2011) Quantitative analysis of culture using millions of digitized books. Science 331:176-182

Rauhvargers A (2011) Global university rankings and their impact. European University Association, Brussels. www.eua.be

Rauhvargers A (2013) Global university rankings and their impact-Report II. European University Association, Brussels. www.eua.be

Robinson D (2013) The mismeasure of higher education? The corrosive effect of university rankings. Ethics Sci Environ Polit 13:65-71

Saisana M, d'Hombres B, Saltelli A (2011) Rickety numbers:

Editorial responsibility: Penny Kuhn,

Oldendorf/Luhe, Germany volatility of university rankings and policy implications. Res Policy 40:165-177

Salmi J, Saroyan A (2007) League tables as policy instruments: uses and misuses. Higher Educ Manag Policy 19: 24-62

Setar L MacFarland M (2012) Top 10 fastest-growing industries. Special Report April 2012. www.ibisworld.com (accessed 13 September 2013)

Shin JC, Kehm B (eds) (2012) Institutionalization of worldclass university in global competition. Springer, London

Shin JC, Toutkoushian RK, Teichler U (eds) (2011) University rankings: theoretical basis, methodology and impacts on global higher education. Springer, London

Stergiou KI, Lessenich S (2013) On impact factors and university rankings: from birth to boycott. Ethics Sci Environ Polit 13:101-111

Stergiou KI, Tsikliras AC (2013) Global university reputation and rankings: insights from culturomics. Ethics Sci Environ Polit 13:193-202

Stratilatis C (2014) University rankings and the scientification of social sciences and humanities. Ethics Sci Environ Polit 13:177-192

Taylor M, Perakakis P, Trachana V, Gialis S (2014) Rankings are the sorcerer's new apprentice. Ethics Sci Environ Polit 13:73-99

Tsikliras AC, Robinson D, Stergiou KI (2014) Which came first: the money or the rank? Ethics Sci Environ Polit 13:203-213

Turner DA (2013) World class universities and international rankings. Ethics Sci Environ Polit 13:167-176

UNESCO (2000) World Education Report 2000 The right to education - towards education for all throughout life. UNESCO Publications, Rome

Wildavsky B (2012) The great brain race: how global universities are reshaping the world. Princeton University Press, Princeton, NJ

Submitted: December 10, 2013 ; Accepted: January 7, 2014 Proofs received from author(s): April 2, 2014 